\title{
PCR IN THE DIAGNOSIS OF CUTANEOUS TUBERCULOSIS
}

\author{
Mauricio Morishi Ogusku*; Aya Sadahiro²; Mário Hiroyuki Hirata ${ }^{3}$; Rosário D. C. Hirata ${ }^{3}$; Clarisse Zaitz ${ }^{4}$; \\ Júlia Ignez Salem ${ }^{1}$
}

\begin{abstract}
${ }^{1}$ Coordenação de Pesquisas em Ciências da Saúde, Instituto Nacional de Pesquisas da Amazônia, Manaus, AM, Brasil;
${ }^{2}$ Instituto de Ciências Biológicas, Universidade Federal do Amazonas, Manaus, AM, Brasil; ${ }^{3}$ Faculdade de Ciências Farmacêuticas, Universidade de São Paulo, São Paulo, SP, Brasil; ${ }^{4}$ Faculdade de Ciências Médicas, Irmandade Santa Casa de Misericórdia de São Paulo, São Paulo, SP, Brasil.
\end{abstract}

Submitted: April 19, 2002; Returned to authors for corrections: August 26, 2002; Approved: May 08, 2003

\begin{abstract}
Seeking to improve the laboratory diagnosis of Cutaneous Tuberculosis, a study was carried out on the application of PCR technique in macerated, decontaminated (with $4 \% \mathrm{H}_{2} \mathrm{SO}_{4}$ for elimination of normal microbiot), neutralized (with $4 \% \mathrm{NaOH}$ ) biopsies tissues samples stored at $-20^{\circ} \mathrm{C}$. Of the 37 samples submitted for study, $16.22 \%$ were positive by microscopy for acid-fast bacilli (concentrated method) and in $43.24 \%$ the Mycobacterium tuberculosis was isolated in Löwenstein-Jensen medium. Using a M. tuberculosis complex specific primer set (gene sequence for 16S rDNA), the mycobacterial DNA was detected in $24.32 \%$ of the biopsies. The sensitivity and specificity of PCR were $43.7 \%$ and $90.4 \%$, respectively. Due to low sensitivity and discrepant results between bacteriological techniques and PCR methodology, the samples were repeated in a new PCR with primers for the IS6110 target. The sensitivity and specificity of PCR for the IS6110 target obtained $100 \%$ in comparison with the culture method. The results confirm the effectiveness of PCR methodology using primers for the IS6110 gene sequence and permit the PCR method to be applied to frozen cutaneous biopsies sent by services that do not identify the M. tuberculosis by the biology molecular method.
\end{abstract}

Keywords: Mycobacterium tuberculosis, cutaneous tuberculosis, Polymerase Chain Reaction (PCR), laboratory diagnosis

\section{INTRODUCTION}

The first report on cutaneous lesion caused by Mycobacterium tuberculosis was dated 1826, when Laennec described and denominated as "pathologist's ulcer" (13), the lesions originated by accidental wounds during necropsy procedures in individuals whose deaths were caused by Tuberculosis. Afterwards, M. tuberculosis was related to cutaneous lesions with great diversity of clinical and histopathological aspects. This diversity has a direct relation with the individual's immunological status, the mycobacteria virulence, the infection circumstances and the presence or not of mycobacteria in the lesion.
The cutaneous lesion can occur by direct penetration of $M$. tuberculosis in the dermis (primary infection) or by dissemination of the same, beginning with a pulmonary focus (secondary infection). According to Salem (personal communication), that in Manaus, Amazonas, in $42.5 \%$ of patients with Cutaneous Tuberculosis (CTb), M. tuberculosis was isolated from pulmonary secretions. This result shows the high incidence by secondary infection and emphasizes the necessity of searching for primary Tuberculosis in organs, mainly the lungs.

The histopathological characteristics and the presence of acid-fast bacilli (AFB) are not pathognomonics of lesion caused by M. tuberculosis. For this reason, among the methods for the diagnosis of $\mathrm{CTb}$, culture from biopsy tissue is regarded as the

\footnotetext{
* Corresponding author. Mailing address: Instituto Nacional de Pesquisas da Amazônia - INPA, Coordenação de Pesquisas em Ciências da Saúde - CPCS, Laboratório de Micobacteriologia, Av. André Araújo, 2936. 69060-001, Manaus, AM, Brasil. E-mail: mmogusku@inpa.gov.br
} 
"Gold Standard". By the culture method it is possible to isolate the M. tuberculosis from the concentration of $100 \mathrm{AFB} / \mathrm{mL}$ of processed samples (2). However, the time required for the isolation and the subsequent biochemical analysis for identification of mycobacteria, can take up to eight weeks (10). On the other hand, the direct acid-fast microscopy on specimens using Ziehl-Neelsen or Kinyoun stain is quick and easy. However, the acid-fast microscopy has a minimum limit of detection of $10,000 \mathrm{AFB} / \mathrm{mL}$ of processed samples, whose sensitivity can change from 22 to $78 \%$ in the cases in which $M$. tuberculosis is isolated in culture (15). Thus, low concentrations of mycobacteria as occurs in CTb (6), make the acid-fast microscopy to be of very low sensibility besides not allowing for distinction between M. tuberculosis complex organism and other species of the genus Mycobacterium.

Among the modern techniques of molecular biology for diagnosis of infectious diseases, the Polymerase Chain Reaction - PCR (14) is a powerful method. It offers the potential for the same day diagnosis of infection, like acid-fast microscopy, using similar mycobacteria concentration to the culture (9) and it is able to define the etiologic agent (11).

In studies of application of PCR in formalin-fixed and paraffinembedded tissues $(5,12,16,22)$ to detect mycobacterial gene sequences that code for $65 \mathrm{kDa}$ (GroEL), $m t p 40,16 \mathrm{~S}$ rDNA or IS6110 the sensitivity of PCR presented a range from $47 \%$ to $87 \%$. This variation, probably, occurs in consequence of the histopathological fixative or time of fixation used in preparation of the paraffin-embedded tissues $(1,8)$ or due to the chosen gene target sequence.

In accordance with the described data, the analysis was carried out on the usefulness of PCR in the diagnosis of CTb in specimens without the interference of histopathological fixatives and in an endemic region of atypical mycobacteria in the skin $(18,19)$. The sensitivity and specificity of PCR technique in macerated, frozen tissues samples suspect of M. tuberculosis infection were compared with the results obtained by the classical culture methodology.

\section{MATERIALS AND METHODS}

\section{Clinical specimens}

Thirty-seven skin biopsies samples obtained from skin lesions of patients with evidence of $M$. tuberculosis infection were analysed by bacteriological (concentrated acid-fast microscopy and culture) and PCR method. Skin biopsies were made in closed lesions (papules, nodules, tumors) and on the edge of open lesions with a punch (minimum diameter of $4 \mathrm{~mm}$ ). In the cases of open lesions, the locality between the necrotic area and the surrounding apparently healthy skin was chosen (17). Keeping in mind the quality and representiveness of the samples, all skin fragments were composed of epidermis, dermis and hypodermis. The collected specimens were transferred in sterile saline solution $(0.85 \% \mathrm{NaCl})$ and sent to the microbiology laboratory. If necessary, samples can be stored at $4^{\circ} \mathrm{C}$ up to 24 hours, before processing in the laboratory. Of the skin biopsies, 9 were collected from the leg; 8 , neck; 4 , face; 4 , foot; 3 , thorax; 2, arm; 1, armpit; 1 , groin; 1 , buttock; 1 , multiple skin lesions (from a patient with AIDS) and 3, unknown. The negative control group for the analysis the procedures of PCR was constituted by 20 samples obtained from lesions of patients with cutaneous carcinoma.

\section{Sample processing of culture for acid-fast bacilli}

As recommended by Salem et al. (19), a portion of biopsy tissue was macerated manually in a sterile mortar, and was decontaminated with $4 \% \mathrm{H}_{2} \mathrm{SO}_{4}$ for $10 \mathrm{~min}$. The mixture was neutralized with $4 \% \mathrm{NaOH}(\mathrm{pH} 6.8-7.0)$, centrifuged at $3000 \mathrm{x} g$ for $15 \mathrm{~min}$, and the pellet was resuspended in $4 \mathrm{~mL}$ of sterile distilled water. Aliquots $(200 \mu \mathrm{L})$ were then inoculated onto 9 slants of media (Löwenstein-Jensen and Löwenstein-Jensen pyruvate incubated in $30^{\circ} \mathrm{C}$ and $37^{\circ} \mathrm{C}$ for 8 weeks) and an aliquot of $1.5 \mathrm{~mL}$ was stored at $-20^{\circ} \mathrm{C}$ for later DNA extraction, and analysis by PCR technique (by this procedure, specimens had the DNA extracted after six years about). From the remaining suspension, smears were prepared for acid-fast microscopy using Kinyoun method (10). The cultures were examined weekly for the growth. Bacterial colonies were identified as $M$. tuberculosis by conventional identification methods (10).

\section{DNA extraction}

An aliquot of $200 \mu \mathrm{L}$ of processed tissue was thawed at room temperature, transferred to a $1.5 \mathrm{~mL}$ sterile microfuge tube, and centrifuged at $12,000 \times \mathrm{g}$ for $5 \mathrm{~min}$. The supernatant was then removed and the pellet resuspended in $200 \mu \mathrm{L} \mathrm{TE}(10 \mathrm{mM}$ Tris- $\mathrm{HCl} \mathrm{pH} 8.0$ and $0.5 \mathrm{mM}$ EDTA). After vortexing, the sample was pelletted by centrifugation at 12,000 $\mathrm{x} g$ for $5 \mathrm{~min}$, and the supernatant was removed. The sample was resuspended in 250 $\mu \mathrm{L}$ of lysis buffer (100 mM Tris-HCl pH 8.0, 5 mM EDTA, $1 \%$ Tween 20, $1 \%$ Triton X-100 and $4 \mathrm{mg} / \mathrm{mL}$ Proteinase K (Gibco, Gaithersburg, MD). The mixture was incubated overnight at $56^{\circ} \mathrm{C}$. Then the sample was incubated for $10 \mathrm{~min}$ at $95^{\circ} \mathrm{C}$. The DNA from the emulsified tissue sample was purified with phenolchloroform and precipitated with $99 \%$ ethanol (4).

\section{Primers and PCR Procedures}

Primers sequences for 16S rDNA target (16) of genus Mycobacterium were: A (5' AGA GTT TGA TCC TGG CTC AG 3') and 247 (5' TTT CAC GAA CAA CGC GAC AA 3'). Primer pair A/247 amplifies a $590 \mathrm{bp}$ fragment, including the variable region V2 that contains the specific sequences for each mycobacterial species. For rapid identification of M. tuberculosis DNA, an inner primer tb (5' ACC ACA AGA CAT GCA TCC CG 3 ') for the Nested-PCR (primer pair A/tb) was used, resulting in a second fragment of $193 \mathrm{bp}$. 
Also for control procedures in PCR and Nested-PCR assays for $16 \mathrm{~S}$ rDNA target, primers $\beta$-actin 5' (5' AGC GGG AAA TCG TGC GTG 3') and $\beta$-actin 3' (5' CAG GGT ACA TGG TGG TGC 3 ') for the gene sequence of $\beta$-actin (16), as an internal control of the amplification reaction were included. Thus, for each tissue sample, the amplification of the $\beta$-actin fragment (304 bp) indicated a successful DNA extraction, besides the absence of Taq DNA Polymerase inhibiters. For each amplification assay, an appropriate negative control (without DNA) and a positive control (DNA from M. tuberculosis H37Rv) were included.

For PCR (primers for $16 \mathrm{~S}$ rDNA), $1-10 \mu \mathrm{L}$ of DNA were added to a mixture containing buffer (10 mM Tris- $\mathrm{HCl} \mathrm{pH} 9.0,1.5 \mathrm{mM}$ $\mathrm{MgCl}_{2}, 50 \mathrm{mM} \mathrm{KCl}$ ), $200 \mu \mathrm{M}$ of dNTPs (Pharmacia Uppsala, Sweden), $1 \mu \mathrm{M}$ of primer A, $1 \mu \mathrm{M}$ of primer $247,1 \mu \mathrm{M}$ of primer $\beta$-actin 5', $1 \mu \mathrm{M}$ of primer $\beta$-actin 3' and $2 \mathrm{U}$ Taq DNA Polimerase (Pharmacia Uppsala, Sweden) in a final volume of $50 \mu \mathrm{L}$. The step-cycle programme was set to denature at $94^{\circ} \mathrm{C}$ for $5 \mathrm{~min}$, and then for 35 cycles at $94^{\circ} \mathrm{C}$ for $1 \mathrm{~min}, 57^{\circ} \mathrm{C}$ for $1 \mathrm{~min}, 72^{\circ} \mathrm{C}$ for $1 \mathrm{~min}$ and a final $72^{\circ} \mathrm{C}$ for $7 \mathrm{~min}$, in a DNA thermal Cycler 2400 (PerkinElmer Cetus).

Aliquots of $5 \mu \mathrm{L}$ from the PCR were taken for the NestedPCR for identification of $M$. tuberculosis DNA. $1 \mu \mathrm{M}$ of primer A and $1 \mu \mathrm{M}$ of primer tb in the reaction mixture $(50 \mu \mathrm{L})$ were used. The cycling conditions were the same as the PCR.

Afterwards, the specimens that were (i) negative NestedPCR and culture-positive for M. tuberculosis, (ii) positive by microscopy and contaminated or negative culture, and (iii) positive Nested-PCR, microscopy-negative and contaminated culture were repeated in a new PCR using primers for the IS6110 gene sequence (7) of M. tuberculosis. Primers sequences for IS6110 target were IS-1 (5' CTC GTC CAG CGC CGC TTC GG 3') and IS-2 (5' CCT GCG AGC GTA GGC GTC GG 3'), which amplify a fragment of $123 \mathrm{bp}$.

PCR for IS6110 was performed in a $50 \mu \mathrm{L}$ mixture containing 1-10 $\mu \mathrm{L}$ of DNA, buffer (10 mM Tris-HC1 pH 9.0, $2 \mathrm{mM} \mathrm{MgCl}_{2}, 50$ $\mathrm{mM} \mathrm{KCl}$ ), $200 \mu \mathrm{M}$ of dNTPs (Pharmacia Uppsala, Sweden), 0.1 $\mu \mathrm{M}$ of primer IS-1, $0.1 \mu \mathrm{M}$ of primer IS-2, 5\% DMSO and $2 \mathrm{U}$ Taq DNA Polymerase (Pharmacia Uppsala, Sweden). The step-cycle programme was set to denature at $94^{\circ} \mathrm{C}$ for $5 \mathrm{~min}$ and then for 35 cycles at $94^{\circ} \mathrm{C}$ for $1 \mathrm{~min}, 68^{\circ} \mathrm{C}$ for $1 \mathrm{~min}, 72^{\circ} \mathrm{C}$ for $1 \mathrm{~min}$ and a final $72^{\circ} \mathrm{C}$ for $7 \mathrm{~min}$, in a DNA thermal Cycler 2400 (Perkin-Elmer Cetus).

\section{Detection of PCR Product}

The PCR and Nested-PCR products $(5 \mu \mathrm{L})$ were run in $1.5 \%$ and $2 \%$ agarose gel electrophoresis in TBE buffer, respectively. Afterwards, the DNA bands were stained with ethidium bromide solution $(0.5 \mu \mathrm{g} / \mathrm{mL})$ and detected by UV transillumination.

\section{Statistical analysis}

The results of DNA amplification tests (Nested-PCR) and culture method were compared. The $2 \times 2$ table was used for determining sensitivity and specificity of the PCR technique.
The analysis of association between PCR and culture methods was made by $x^{2}$ test (qui-square) for independence, and a value $\mathrm{p}<0.05$ was taken as indicative of statistical significance.

\section{RESULTS}

The genomic DNA was extracted from all biopsies tissues and its integrity was verified by amplification of a $\beta$-actin gene segment. All the analyzed samples presented the expected DNA product of $304 \mathrm{bp}$ (Fig. 1). After Nested-PCR, as can be seen in the Fig. 2, the M. tuberculosis DNA (amplified product of 193 bp) was observed in positive control (lane P) and in some specimens (lanes 1, 2 and 3).

The bacteriological data and Nested-PCR results using primer for $16 \mathrm{~S}$ rDNA are presented in Table 1 . The acid-fast microscopy was positive in 6 of $37(16.22 \%)$ cases with clinical evidence of CTb, Nested-PCR in 9 of $37(24.32 \%)$ and the culture was positive for M. tuberculosis in 16 of 37 (43.24\%). However,

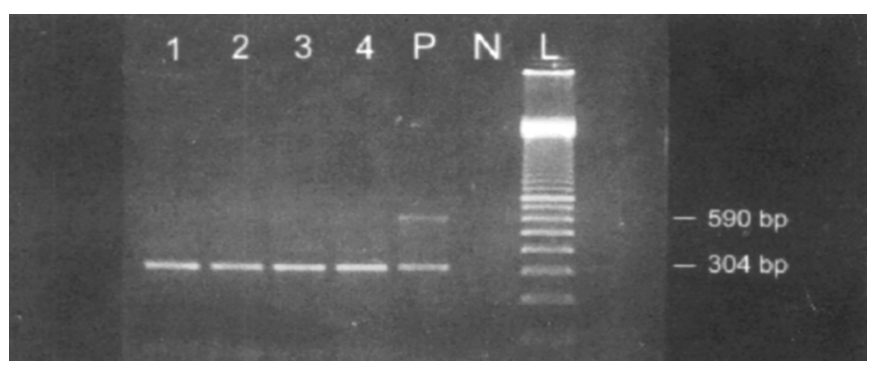

Figure 1. Gel electrophoresis of PCR products, using primers for $\beta$-actin and 16S rDNA genes: positive (lanes 1, 2, 3 and 4) for

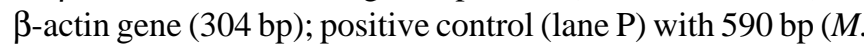
tuberculosis H37Rv DNA) and 304 bp (human DNA); negative control (lane N) without DNA and 100 bp DNA ladder (lane L).

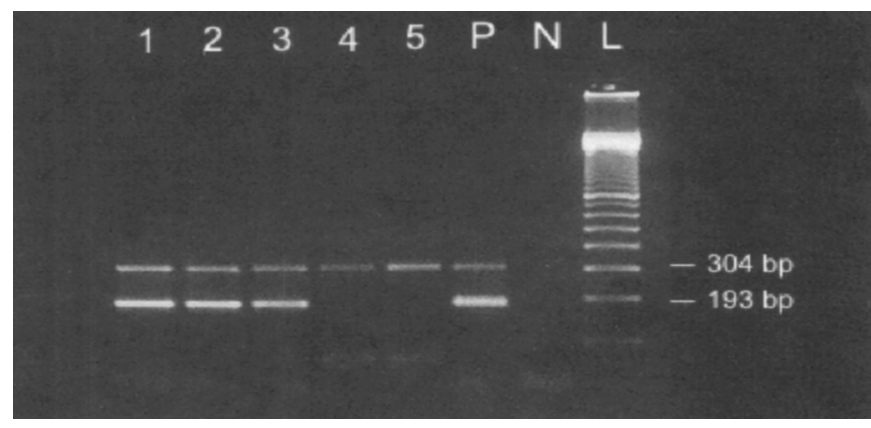

Figure 2. Gel electrophoresis of Nested-PCR products, using primers for $\beta$-actin and 16S rDNA genes: positive (lanes 1, 2, 3,4 and 5) for $\beta$-actin gene (304 bp); positive (lanes 1, 2 and 3) for 16S rDNA (193 bp); positive control (lane P) with $193 \mathrm{bp} \mathrm{(} M$. tuberculosis H37Rv DNA) and 304 bp (human DNA); negative control (lane N) without DNA and 100 bp DNA ladder (lane L). 
Table 1. Comparison of results of Nested-PCR for 16S rDNA and bacteriological methods for M. tuberculosis detection.

\begin{tabular}{|c|c|c|c|c|c|c|c|c|c|c|c|c|c|c|}
\hline \multirow{4}{*}{ Nested-PCR } & \multicolumn{12}{|c|}{ Culture in Löwenstein-Jensen } & & \\
\hline & \multicolumn{4}{|c|}{ Positive for M. tuberculosis } & \multicolumn{4}{|c|}{ Negative } & \multicolumn{4}{|c|}{ Contaminated } & & \\
\hline & \multicolumn{2}{|c|}{$\begin{array}{c}\text { Positive } \\
\text { Microscopy }\end{array}$} & \multicolumn{2}{|c|}{$\begin{array}{c}\text { Negative } \\
\text { Microscopy }\end{array}$} & \multicolumn{2}{|c|}{$\begin{array}{c}\text { Positive } \\
\text { Microscopy }\end{array}$} & \multicolumn{2}{|c|}{$\begin{array}{c}\text { Negative } \\
\text { Microscopy }\end{array}$} & \multicolumn{2}{|c|}{$\begin{array}{c}\text { Positive } \\
\text { Microscopy }\end{array}$} & \multicolumn{2}{|c|}{$\begin{array}{c}\text { Negative } \\
\text { Microscopy }\end{array}$} & \multicolumn{2}{|c|}{ Total } \\
\hline & $\mathrm{N}$ & $\%$ & $\mathrm{~N}$ & $\%$ & $\mathrm{~N}$ & $\%$ & $\mathrm{~N}$ & $\%$ & $\mathrm{~N}$ & $\%$ & $\mathrm{~N}$ & $\%$ & $\mathrm{~N}$ & $\%$ \\
\hline Positive & 2 & 5.41 & 5 & 13.51 & 1 & 2.70 & 0 & 0.00 & 0 & 0.00 & 1 & 2.70 & 9 & 24.32 \\
\hline Negative & 1 & 2.70 & 8 & 21.62 & 0 & 0.00 & 17 & 45.95 & 2 & 5.41 & 0 & 0.00 & 28 & 75.68 \\
\hline Total & 3 & 8.11 & 13 & 35.13 & 1 & 2.70 & 17 & 45.95 & 2 & 5.41 & 1 & 2.70 & 37 & 100.00 \\
\hline
\end{tabular}

of the positive acid-fast microscopy samples, only in 3 cases (8.11\%) were the M. tuberculosis isolated. This fact was due to contamination of the culture medium in two samples and one negative culture for $M$. tuberculosis. In view of the acid-fast microscopy results, all patients were treated with specific drugs for Tuberculosis and, afterwards, were cured.

The M. tuberculosis isolation is regarded as the "Gold Standard" for the diagnosis of CTb. So, the Nested-PCR results for 16S rDNA are shown in the Table 2 for comparison to the culture method. The sensitivity and specificity were $43.75 \%$ and $90.47 \%$, respectively. In spite of low sensitivity, the association analysis between the culture method and Nested$\operatorname{PCR}\left(x^{2}=4.9090\right.$ and $\left.p=0.0267\right)$ presented statistical significance.

Three samples yielded contaminated culture. Of these samples, 2 were positive acid-fast microscopy and negative Nested-PCR, and 1 was negative acid-fast microscopy and positive Nested-PCR.

The samples with discrepant results between bacteriological techniques and Nested-PCR assay (for 16S rDNA gene sequence) had positive results in the new PCR when primers for IS6110 gene sequence were used (Fig. 3).

The samples of the negative control group yielded negative results in Nested-PCR for 16S rDNA and PCR for IS6110 targets.

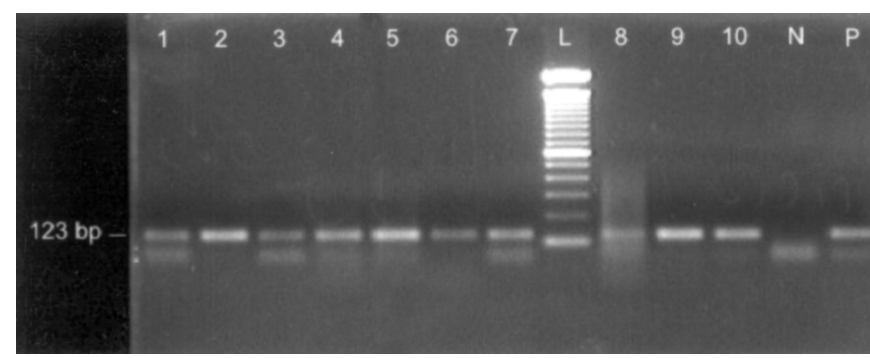

Figure 3. Gel electrophoresis of PCR products, using primers for IS6110 gene: positive (lanes 1, 2, 3, 4, 5, 6, 7, 8, 9 and 10) for IS6110 gene (123 bp); positive control (lane P) with $123 \mathrm{bp} \mathrm{(M.}$ tuberculosis H37Rv DNA); negative control (lane N) without DNA and 100 bp DNA ladder (lane L).
Table 2. Results of Nested-PCR for 16S rDNA and culture method for M. tuberculosis detection.

\begin{tabular}{|c|c|c|c|c|c|c|}
\hline \multirow{3}{*}{ Nested-PCR } & \multicolumn{4}{|c|}{ Culture for M. tuberculosis } & & \\
\hline & \multicolumn{2}{|c|}{ Positive } & \multicolumn{2}{|c|}{ Negative } & \multicolumn{2}{|c|}{ Total } \\
\hline & $\mathrm{N}$ & $\%$ & $\mathrm{~N}$ & $\%$ & $\mathrm{~N}$ & $\%$ \\
\hline Positive & 07 & 18.92 & 02 & 5.41 & 09 & 24.33 \\
\hline Negative & 09 & 24.32 & 19 & 51.35 & 28 & 75.67 \\
\hline Total & 16 & 43.24 & 21 & 56.76 & 37 & $\overline{100.00}$ \\
\hline$x^{2}$ & 909 & & & $=0.02$ & & \\
\hline
\end{tabular}

\section{DISCUSSION}

The results of microscopy for acid-fast bacilli in this study, confirm that the lesions in CTb are paucibacilary in the most cases. In fact, a large number of acid-fast bacilli must be present to be detected by microscopy or histopathologic examination. It indicates the importance of culture method for diagnosis of $\mathrm{CTb}$ in laboratories that do not identify the M. tuberculosis by molecular biology methods. However, in laboratories with technical and instrumental support for molecular typing, the PCR for IS6110 target should be carried out. When results are positive, the PCR should be regarded as conclusive diagnosis, whereas the use of primer set for IS6110 gene sequence increased the sensitivity of PCR methodology to $100 \%$ in samples with suspicious or bacteriological confirmation or in those which the culture was not possible due to contamination of Löwenstein-Jensen medium.

It has already been described that the concentration of extracted DNA from formalin-fixed, paraffin-embedded tissues, did not supply false-positive results in PCR (12). Among the gene sequences used by various investigators, the best results were obtained with the IS6110, a repetitive insertion sequence. For this region, the best primer set amplified a 123 bp sequence. Similar results were obtained in other studies $(3,20,21,23)$. In 
accordance with these authors, the results are due to "a mobile genetic element usually present in multiple copies within genomes of virtually all members of $M$. tuberculosis complex". The presence of repetitive target sequence in the $M$. tuberculosis genome provides a higher sensitivity and stability of PCR assay. When multiple copies of the target sequence are present, the sensitivity of detection of $M$. tuberculosis DNA will increase in proportion to the copy number, without the necessity of performing a NestedPCR. This is a great advantage for detection of $M$. tuberculosis in specimens with low number of mycobacteria as occur in CTb. In fact, in this study, the PCR assay for IS6110 region has shown better results than the $16 \mathrm{~S}$ rDNA target, which is present in a single copy in the genome of $M$. tuberculosis.

Marchetti et al. (12) demonstrated that the DNA concentration (from mycobacteria or not) extracted from clinical samples could interfere in the result of PCR supplying false-negative results. The authors verified that when the DNA quantity was of $5 \mu \mathrm{g}$, the false-negative results for IS6110 occurred in 33\% of the samples. In concentrations from 1 to $3 \mu \mathrm{g}$ of DNA, the falsenegative results occurred in only $13 \%$. So these results demonstrate the strict interdependence of DNA concentration and PCR protocol. It seems to us that the DNA concentrations should be lower than $1 \mu \mathrm{g}$ to avoid the false-negative results. The aliquot of $200 \mu \mathrm{L}$ of clinical specimens used in this study for extraction of DNA, seems to offer DNA concentration that allows a PCR-positive assay without the occurrence of nonmycobacterial DNA interference. Such a premise is based on the positivity of PCR for IS6110 in those samples with strong indications of the presence of $M$. tuberculosis (positivity in acidfast microscopy, culture, or both).

One important aspect in this study is related with the positivity on acid-fast microscopy, absence of etiological definition by the culture, and positivity on PCR for IS6110. Due to the results of PCR, it follows that the positive results on microscopy were not due to the presence of environmental mycobacteria in skin as reported by Salem et al. $(18,19)$.

In conclusion, the results of the present study show that the PCR assay can successfully be used to detect $M$. tuberculosis DNA in macerated and frozen tissue samples for a more rapid, specific and reliable $\mathrm{CTb}$ diagnosis. It offers the possibility of the technique being carried out in stored specimens sent by services that do not identify the $M$. tuberculosis by molecular methods. Moreover, the confirmation of the amplification of mycobacterial DNA in stored tissue samples enables other molecular studies, such as genetic typing, distribution of particular M. tuberculosis strain, and the detection of multiple drugs-resistant $M$. tuberculosis strains.

\section{ACKNOWLEDGMENTS}

This study was supported by the Conselho Nacional de Desenvolvimento Científico e Tecnológico (CNPq),
Coordenação de Aperfeiçoamento de Pessoal de Nível Superior (CAPES)/Programa Rede Norte (RENOR), Secretaria de Políticas de Saúde do Ministério da Saúde, Instituto Nacional de Pesquisas da Amazônia - INPA, and Centro de Estudos Dermatológicos "Adolpho Carlos Lindenberg" - Irmandade Santa Casa de Misericórdia de São Paulo. The authors thank Jorge Ivan R. Porto, Ph.D., Maria Cristina dos Santos, Ph.D., Megumi Sadahiro, M.Sc. for their excellent assistance and Mr. George Nakamura for revision in English.

\section{RESUMO}

\section{Técnica de reação em cadeia da polimerase (PCR) no diagnóstico da tuberculose cutânea}

Visando melhorar o diagnóstico laboratorial da Tuberculose Cutânea, foi realizado o estudo da aplicação da técnica de PCR em amostras de tecidos cutâneos macerados, descontaminados (com $\mathrm{H}_{2} \mathrm{SO}_{4} 4 \%$ para eliminação da microbiota normal), neutralizados (com NaOH 4\%) e armazenadas a $-20^{\circ} \mathrm{C}$. Das 37 amostras submetidas ao estudo, 16,22\% apresentavam baciloscopias positivas para bacilos álcool-ácidos resistentes (método concentrado) e em $43,24 \%$ houve o isolamento do Mycobacterium tuberculosis em meio de cultivo LöwensteinJensen. Utilizando-se de primers para a região $16 \mathrm{~S}$ rDNA do $M$. tuberculosis, o DNA micobacteriano foi detectado em $24,32 \%$ das biópsias. A sensibilidade e especificidade da PCR foram $43,7 \%$ e 90,4\%, respectivamente. Devido à baixa sensibilidade e resultados divergentes entre as técnicas bacteriológicas e PCR (para a seqüência 16S rDNA), as amostras foram repetidas em um novo PCR com primers para a região IS6110. Tanto a sensibilidade como a especificidade da PCR com primers para IS6110 alcançaram 100\% em relação ao cultivo. Os resultados confirmam a eficácia da PCR utilizando primers para a sequiência IS6110 e oferecem a possibilidade da técnica ser aplicada em amostras congeladas enviadas por serviços que não identificam o M. tuberculosis por técnicas de biologia molecular.

Palavras-chave: Mycobacterium tuberculosis, tuberculose cutânea, Reação em Cadeia da Polimerase (PCR), diagnóstico laboratorial

\section{REFERÊNCIAS}

1. Ben-Ezra, J.; Johnson, D.A.; Rossi, J.; Cook, N.; Wu, A. Effect of fixation on the amplification of nucleic acids from paraffin-embedded material by polymerase chain reaction. J. Histochem. Cytochem., 39: 351-354, 1991

2. Butcher, P.D.; Hutchinson, N.A.; Doran, T.J.; Dale, J.W. The application of molecular techniques to the diagnosis and epidemiology of mycobacterial diseases. In: Mycobacterial disease - old problems, new solutions. (Supplement) J. Apl. Bacteriol., 81: 53S-71S, 1996

3. Cave, D.M.; Eisenach, K.D.; McDermott, P.F.; Bates, J.H.; Crawford J. IS6110: conservation of sequence in the Mycobacterium 
tuberculosis complex and its utilization in DNA fingerprinting. Mol. Cell. Probes, 5: 73-80, 1991.

4. Davis, L.G.; Kuehl, W.M.; Battey, J.F. Basic Methods in Biology Molecular. Appleton \& Lange, Norwalk, Connecticut, 1994, 775p.

5. Degitz, K.; Steidl, M.; Neubert, U.; Plewig, G.; Volkenandt, T.M. Detection of mycobacterial DNA in paraffin-embedded specimens of lupus vulgaris by polymerase-chain rection. Arch. Dermatol. Res., 285: $168-170,1993$.

6. Degitz, K. Detection of mycobacterial DNA in the skin. Arch. Dermatol., 132:71-75, 1996.

7. Eisenach, K.D.; Cave, M.D.; Bates, J.H.; Crawforf, J.T. Polymerase chain reaction amplification of a repetitive DNA sequence specific for Mycobacterium tuberculosis. J. Infect. Dis., 161: 977-981, 1990.

8. Fiallo, P.; Williams, D.L.; Chan, G.P.; Gillis, T.P. Effects of fixation on polymerase chain reaction detection of Mycobacterium leprae. J. Clin. Microbiol., 30: 3095-3098, 1992.

9. Hance, A.J.; Grandchanp, B.; Levy-Frebault, V.; Lecossier, D.; Rausier, J.; Bocart, D.; Gicquel, B. Detection and identification of mycobacteria by amplification of mycobacterial DNA. Mol. Microbiol., 3: 843-849, 1989.

10. Kant, P.T.; Kubica, G.M. Public Health Mycobacteriology. A guide for the level III Laboratory. U.S. Department of Health Education and Welfare, C.D.C., Atlanta, Georgia, U.S.A., 1985.

11. Klatser, P.R. Amplification reactions in mycobacteriology. $J$. Microbiol. Methods., 23: 75-87, 1995.

12. Marchetti, G.; Gori, A.; Catozzi, L.; Vago, L.; Nebuloni, M.; Rossi, M.C.; Esposti, A.D.; Bandera, A.; Franzetti, F. Evaluation of PCR in Detection of Mycobacterium tuberculosis from formalin-fixed, paraffin-embedded tissues: comparison of four amplification assays. J. Clin. Microbiol., 36: 1512-1517, 1998.

13. Marmelzat, W. L. Laennec and the "Prosector's warth". Arch Dermatol., 86: 74-78, 1962.
14. Mullis, K.B.; Faloona, F.A. Specific synthesis of DNA in-vitro via a polimerase catalyzed chain reaction. Methods Enzymol., 155: 335$350,1987$.

15. Pflaller, M.A. Application of new technology to the detection, identification and antimicrobial susceptibility testing by mycobacteria. Clin. Microbiol. Infec. Dis., 101: 329-337, 1994.

16. Richter, E.; Schlüter, C.; Duchrow, M.; Hahn, M.; Rüsch-Gerdes, S.; Galle, J.; Flad, H.; Gerdes, J. An improved method for the speciesspecific assessment of mycobacteria in routinely formalin-fixed and paraffin-embedded tissues. J. Pathol., 75: 85-92, 1995.

17. Salem, J.I. Presença de micobactérias na flora da pele e sua importância em lesões cutâneas. Rio de Janeiro, 1987, 106p. (Ph.D. Thesis. Instituto de Microbiologia. UFRJ).

18. Salem, J.I.; Gontijo Filho, P.P.; Frebault, V.L.; David, H.L. Isolation and characterization of mycobacteria colonizing the healthy skin. Acta Leprol., 7: 18-20, 1989a.

19. Salem, J.I.; Gadelha, A.R.; Maroja, F.; David, H.L. Non-cultivable mycobacteria in ulcers of the skin. Acta Leprol., 7: 10-15, $1989 \mathrm{~b}$.

20. Thierry, D.; Cave, M.D.; Eisenach, K.D.; Crawford, J.T.; Bates, J.H.; Gicquel, B.; Guesdon, J.L. IS6110, an IS-like element of Mycobacterium tuberculosis complex. Nucleic Acids Res., 18: 188, 1990.

21. Van Soolingen, D.; de Haas, P.E.W.; Hermans, P.W.M.; Groenen, P.M.A.; Van Embden, J.D.A. Comparison of various repetitive DNA elements as genetic markers for strain differentiation and epidemiology of Mycobacterium tuberculosis. J. Clin. Microbiol., 31: 1987-1995, 1993.

22. Victor, T.; Jordaan, H.F.; Van Niekerk, D.J.T.; Louw, M.; Jordaan, A.; Van Helden, P.D. Papulonecrotic tuberculid - Identification of Mycobacterium tuberculosis DNA by polymerase chain reaction. Am. J. Dermatopathol., 6: 491-495, 1992.

23. Yuen, L.K.W.; Ross, B.C.; Jackson, K.M.; Dwyer, B. Characterization of Mycobacterium tuberculosis strains from vietnamese patients by southern blot hybridization. J. Clin. Microbiol., 31: 1615-1618, 1993. 